\title{
Вопросы хранения и транслирования культурно-исторического наследия Тувы методами библиотечной работы (на примере деятельности Национальной библиотеки им. А. С. Пушкина Республики Тыва)
}

\section{Чодураа В. Сарыглар}

Национальная библиотека им. А. С. Пушкина Республики Тыва; Государственная публичная научно-техническая библиотека Сибирского отделения Российской академии наук, Российская Федерация

Ирина А. Эртине, Тамара М. Люндуп

Национальная библиотека им. А. С. Пушкина Республики Тыва, Российская Федерация

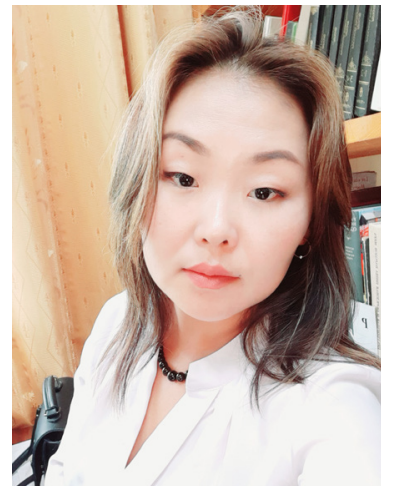

В статье анализируется деятельность библиотек Республики Тыва, связанная с хранением и транслированием культурно-исторического наследия Тувы за период 2011-2021 г2. В соответствии с российскими нормативно-правовыми актами, а также тувинскими государственными программами развития культуры, библиотечная сеть республики (173 библиотеки, в том числе три республиканских - Национальная библиотека РТ, Тувинская республиканская детская библиотека им. К. И. Чуковского, Тувинская республиканская специальная библиотека для незрячих и слабовидящих) реализует цеелый ряд проектов.

В том числе библиотеки проводят статистические и социологические исследования состава читателей, их запросов и интересов. В 2019 г. был составлен список самых читаемых книг. В 2011 г. началась работа по переводу документов в цифровой формат. В оцифровку включены книги по признаку исторической, художественной и музейной ценности изданий, с цеелью создания особых условий для хранения и использования произведений печати. Оцифрованные документы составляют комплексные библиографические и полнотекстовые базы данных, открытый доступ к ним организован на сайте Национальной библиотеки Тувы.

Образовательные проекты выполняются в партнерстве с учебными заведениями рес-

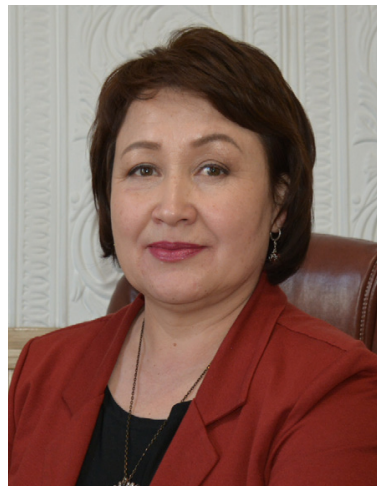
публики. В библиотечных отделах Национальной библиотека РТ действуют Малая академия наук и Школа аспиранта; работают проекты «Школа развития личности», «Библиотека. Информация. Образование - Жизнь» и др. Социальные проекты направлены на поддержку творческого развития людей разных возрастов и категорий, в том числе «БиблиоЮрта» (выезды на чабанские стоянки), «Читает мама, читает папа» (видеозапись чтений книг родителей, отбывающих наказание в исправительных учреждениях, для последующей передачи их детям) и др. Популяризация краеведческого наследия республики (культурные проекты) выполняется в форме подготовки электронной библиотеки «Тува читающая», проекта «Открывая прошлое» и пр.

Ключевые слова: библиотека; культурное наследие; культура Тувы; Тува; Тува читающая; библиотечное дело; современная библиотека; электронная книга; культурный проект; социальный проект; образовательный проект

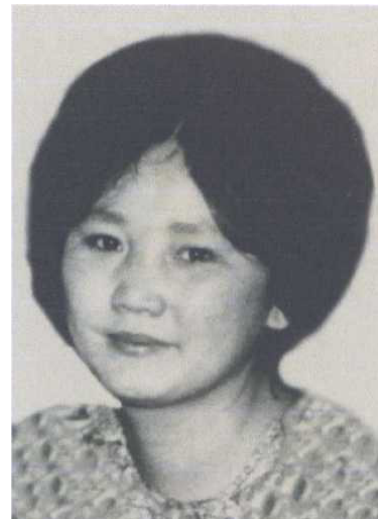

\section{Для цитирования:}

Сарыглар Ч. В., Эртине И. А., Люндуп Т. М. Вопросы хранения и транслирования культурно-исторического наследия Тувы методами библиотечной работы (на примере деятельности Национальной библиотеки им. А. С. Пушкина Республики Тыва) // Новые исследования Тувы. 2021, № 2. С. 130-144. DOI: https://www.doi.org/10.25178/nit.2021.2.11

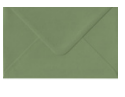

Сарыглар Чодураа Викторовна - ученый секретарь Национальной библиотеки им. А. С. Пушкина Республики Тыва; аспирант Государственной публичной научно-технической библиотеки Сибирского отделения Российской академии наук. Адрес: 667000, Россия, г. Кызыл, ул. Ленина, д. 21; 630000, Россия, г. Новосибирск, ул. Восход, д. 15. Тел.: +7 (923) 266-62-53. Эл. адрес: choduraa-m@yandex.ru

Эртине Ирина Алексеевна - директор Национальной библиотеки им. А. С. Пушкина Республики Тыва. Адрес: 667000, Россия, г. Кызыл, ул. Ленина, д. 21. Тел.: +7 (923) 382-72-62. Эл. адрес: nblibrary@mail.ru

Люндуп Тамара Монгушевна - заведующая сектором научно-исследовательской работы научно-методического отдела Национальной библиотеки им. А. С. Пушкина Республики Тыва. Адрес: 667000, Россия, г. Кызыл, ул. Ленина, д. 21. Тел.: +7 (983) 369-34-19. Эл. адрес: tamaralundup@yandex.ru 
Article

\title{
Preserving and promoting the cultural and historical heritage of Tuva by means of library work: the case of the A.S. Pushkin National Library of the Republic of Tuva
}

\author{
Choduraa V. Saryglar \\ A.S. Pushkin National Library of the Republic of Tuva; \\ State Public Research and Technology Library, Siberian Branch of the Russian Academy of Sciences, Russian Federation
}

Irina A. Ertine, Tamara M. Liundup

A.S. Pushkin National Library of the Republic of Tuva, Russian Federation

\begin{abstract}
The article examines the work of libraries in the Republic of Tuva which deals with storing and promoting Tuva's cultural and historical heritage in the second decade of the new millennium. In compliance with Russia's federal legislation and Tuvan state-run programs for supporting cultural development, a number of projects are carried on by the 173 libraries which comprise the region's library network. The network, among others, includes three regional-level libraries: the National Library of the Republic of Tuva, K.I. Chukovsky Regional Children's Library, and the Regional Library of Tuva for the Visually Impaired.

The network conducts a number of studies, including statistical and sociological research in the structure of their readership, their requests and interests. In 2019, a list of the most frequently checked-out books was complied. Since 2011, library collections have been digitalized, with a special focus on books of considerable historical, artistic and museum value, in order to set up special conditions for storing and accessing books. Digitalized documents have been compiled into bibliographical and full-text databases, openly accessible at the site of the National Library.

For educational projects, libraries enter in partnerships with the region's educational institutions. The National Library hosts the Small Academy of Sciences and the School for Postgraduates; such projects as the School of Personal Development, and Library. Information. Education. - Life, use the library as their venue. Social projects aim to support creative development of people of different ages and groups. These projects include the BiblioYurt (outreach events at shepherds'stations, and "Mom and Dad Read" (filming book readings by parents currently doing their sentences, to be later given to their children). Among cultural initiatives promoting the region's local history are the "Tuva Reads" electronic library and "Discovering the Past" project
\end{abstract}

Keywords: library; cultural heritage; culture of Tuva; Tuva; Tuva reads; library work; contemporary library; e-book; cultural project; social project; educational project

\footnotetext{
For citation:
Saryglar Ch. V., Ertine I. A. and Liundup T. M. Voprosy khraneniia i translirovaniia kul'turno-istoricheskogo naslediia
Tuvy metodami bibliotechnoi raboty (na primere deiatel'nosti Natsional'noi biblioteki im. A. S. Pushkina Respubliki
Tyva) [Preserving and promoting the cultural and historical heritage of Tuva by means of library work: the case of the
A.S. Pushkin National Library of the Republic of Tuva]. New Research of Tuva, 2021, no. 2, pp. 130-144. (In Russ.). DOI:
https://www.doi.org/10.25178/nit.2021.2.11

For citation Tyva) Preserving and prom A.S. Pushkin National Library of the Republic of Tuva]. New Research of Tuva, 2021, no. 2, pp. 130-144. (In Russ.). DOI:
} Postgraduate student, State Public Research and Technology Library, Siberian Branch of the Russian Academy of Sciences. Postal address: 21 Lenin St., 667000, Kyzyl, Russian Federation; 15 Voskhod St., Novosibirsk, 630000, Russian Federation. Tel.: +7 (923) 266-62-53. E-mail: choduraa-m@yandex.ru

SARYGLAR, Choduraa Viktorovna, Academic Secretary, A. S. Pushkin National Library of the Republic of Tuva

ORCID ID: 0000-0002-6338-5281 ERTINE, Irina Alekseevna, Director, A. S. Pushkin National Library of the Republic of Tuva. Postal address: 21 Lenin St., 667000, Kyzyl, Russian Federation. Tel.: +7 (923) 382-72-62.E-mail: nblibrary@mail.ru

LUNDUP, Tamara Mongushevna, Head, Sector of Research, Scientific and Methodological Department, A. S. Pushkin National Library of the Republic of Tuva. Postal address: 21 Lenin St., 667000, Kyzyl, Russian Federation. Tel.: +7 (983) 369-34-19. E-mail: tamaralundup@yandex.ru 


\section{Введение}

В деле хранения и транслирования культурно-исторического наследия Тувы используются разные методы. Среди них важен метод библиотечной работы, тесно связанный с общими задачами развития сферы культуры республики. Ведущей организацией в этом направлении является Национальная библиотека им. А. С. Пушкина Республики Тыва, отмечающая в текущем году 90-летний юбилей.

Библиотечное дело и его комплексный, интегральный характер, особенно на современном этапе, уже хорошо изучены российскими исследователями (Карташов, 2004; Ванеев, 2007; Столяров, 1991; Фирсов, 2000; Дворкина, 2009; Фонотов, 2002; Артемьева, 2012; Тюлина, 1989; Кукатова, 2010). Во многих публикациях библиотечное дело рассматривается в социокультурном комплексе региона (Пайчадзе, 1983; Посадсков, 2012; Ситников, 1985; Гузнер, 1995; Лукьянова, 2009; Маслова, 2010, и др.). Библиотечное и книжное дело Тувы также вошло в поле внимания авторов, в т. ч. авторов данной статьи (Фенцель, 1997ab, 2003, 2011, 2014; Подик, 2017; Чадамба, 2006; Люндуп, 2006; Кошкар-оол, 1990; Маадыр, 1997; Монгуш, 2007; Кравченко, Фенцель, 2017; Эртине, 2020; Сарыглар, 2020, 2021; Наныкпан, 2016 и др.).

Сегодня важно исследовать такую сторону деятельности тувинских библиотек, как хранение и транслирование культурно-исторического наследия Тувы, мало затронутую в упомянутых трудах. Также другим аспектом новизны статьи является тот факт, что указанную проблему мы проанализируем на примере деятельности Национальной библиотеки им. А. С. Пушкина РТ (далее - НБ РТ) за последние десять лет - 2011-2021 гг. ${ }^{1}$

Соответственно, для достижения данной цели мы сначала проанализируем особенности транслирования культурно-исторического наследия Тувы, определим роль НБ РТ в сохранении историкокультурного наследия и рассмотрим ее проектную деятельность НБ РТ, в которой методами библиотечной работы решаются задачи хранения и транслирования культурно-исторического наследия республики.

Методологической базой исследования являются труды известных библиотековедов, книговедов (Карташов, 2004; Артемьева, 2012; Кожевникова, 2012; Маслова, 2010; Кукатова, 2010; Фенцель, 2014). Источниковую базу составили нормативно-правовая документация, регулирующая деятельность библиотек, отчетные материалы библиотеки 2010-2020 гг., документный фонд и электронный каталог библиотеки, а также публикации в СМИ Тувы. Исследование выполнено на основе использования метода непосредственного статистического анализа, наблюдения за практикой деятельности библиотеки. На основе средового и пространственного подходов изучается взаимодействие библиотеки с социально-культурными учреждениями.

\section{Научная исследованность}

Различные аспекты деятельности национальных библиотек стали объектом пристального внимания таких библиотековедов, как А. Н. Ванеев (Ванеев, 2007), Ю. Н. Столяров (Столяров, 1991), В. Р. Фирсов (Фирсов, 2000), М. Я. Дворкиной (Дворкина, 2009), Г. П. Фонотова (Фонотов, 2002), Е. Б. Артемьевой (Артемьева, 2012). Серьезное исследование типологических особенностей национальных библиотек было проведено Н. И. Тюлиной (Тюлина, 1989). Систему центральных библиотек субъектов РФ и характер их развития определила Г. И. Кукатова (Кукатова, 2010). Во многих публикациях библиотечное дело рассматривается в социокультурном комплексе региона. Над историей библиотек региона много и плодотворно работали сибирские книговеды С. А. Пайчадзе (Пайчадзе, 1983), А. Л. Посадсков (Посадсков, 2012), Л. А. Ситников (Ситников, 1985), И. А. Гузнер (Гузнер, 1995) и библиотековеды Л. С. Лукьянова (Лукьянова, 2009), А. Н. Маслова (Маслова, 2010) и др.

Отдельное внимание уделяется и библиотечному делу отдельных территорий, в том числе национальных образований. Так, к библиотечному и книжному делу Тувы обращались многие ученые

\footnotetext{
${ }^{1}$ Выбор этого периода связан с реализацией Республиканской целевой программы «Модернизация библиотечной системы Республики Тыва», начиная с 2011 г., когда была проведена масштабная работа по модернизации библиотечных процессов Национальной библиотеки им. А. С. Пушкина Республики Тыва и в центральных районных библиотеках ЦБС республики. В республиканских библиотеках: Национальной библиотеке им. А. С. Пушкина, Тувинской республиканской специальной библиотеке для незрячих и слабовидящих, Тувинской республиканской детской библиотеке им. К. И. Чуковского и в семнадцати центральных районных библиотеках были созданы информационные центры.
} 
библиотековеды и книговеды. В 1990 г. защитила диссертацию В.А. Кошкар-оол с темой «Библиотечное строительство в Тувинской АССР (История, современное состояние и перспективы развития)» (Кошкар-оол, 1990). В 1998 г. защищена диссертация М. С. Маадыр, посвященная истории книжной культуры, организации и совершенствованию в Туве книгоиздательского дела (Маадыр, 1997). История развития библиографии Тувы отражена в работе 3. М. Монгуш (Монгуш, 2007). Изучению чтения среди населения республики посвящена диссертация И. В. Подик (Подик, 2017).

Особо следует отметить научно-исследовательский вклад О. В. Фенцель. В 1997 г. у нее вышла «История формирования фондов библиотек Тувы до 1917 г.» (Фенцель, 1997b). В 2003 г. она защитила кандидатскую диссертацию «Библиотечное краеведение в Республике Тува: прошлое, настоящее, перспективы» (Фенцель, 2003). Будучи уже директором НБ РТ, она продолжала заниматься изучением библиотечного дела Тувы, прежде всего в плане истории развития библиотеки. Итогом стали монографии: «История становления и развития Национальной библиотеки Республики Тыва (1914-2010 гг.)» (Фенцель, 2011), «Библиотечное дело Тувы в контексте историко-культурного пространства региона» (Фенцель, 2014). В целом ее труды посвящены достижениям, проблемам и перспективам библиотечного дела в контексте историко-культурного пространства региона.

Как мы видим, истории Национальной библиотеки Тувы уделено много внимания. Тем не менее, проходит время, десятилетия и уже встают новые исследовательские задачи.

\section{Особенности транслирования культурно-исторического наследия Тувы}

В соответствии со статьей 3 Закона Российской Федерации от 9 октября 1992 г. № 3612-1 «Основы законодательства Российской Федерации о культуре» под культурным наследием народов Российской Федерации понимаются материальные и духовные ценности, созданные в прошлом, а также памятники и историко-культурные объекты и объекты, имеющие значение для сохранения и развития самобытности Российской Федерации и всех ее народов, их вклада в мировую цивилизациюํ.

На реализацию конституционной обязанности беречь памятники истории, культуры направлен Федеральный закон от 25 июня 2002 г. № 73-Ф3 «Об объектах культурного наследия (памятниках истории и культуры) народов Российской Федерации»², а также закон Республики Тыва от 18 января 2013 г. № 1772 ВХ-1 «Об охране и использовании историко-культурного наследия народов Республики Тыва» ${ }^{3}$, которые регулируют отношения в области сохранения, использования и популяризации объектов культурного наследия (памятников истории и культуры) народов Российской Федерации, устанавливают особенности владения, пользования и распоряжения указанными объектами, а также формируют общие принципы государственной охраны объектов культурного наследия.

Культурно-историческое наследие, вслед за рядом авторов, понимается нами как часть материальной и духовной культуры, созданная прошлыми поколениями, выдержавшая испытание временем и передающая следующим поколениям как нечно ценное и почитаемое (Библиотечное обслуживание ..., 2009: 49).

В «Концепции духовно-нравственного развития и воспитания детей и молодежи Республики Тыва до 2025 года» ${ }^{4}$ говорится, что проблема духовно-нравственного воспитания является одной из самых актуальных в образовательной сфере и воспитании молодежи. Библиотеки также вносят вклад в работу сохранности и транслирования культурно-исторического наследия, поскольку хранят и предоставляют доступ к книгам в первую очередь. Чение книг и других печатных произведений остается одним из наиболее универсальных способов формирования духовно-нравственных основ личности у детей и молодежи через обычаи и традиции.

\footnotetext{
1 «Основы законодательства Российской Федерации о культуре» (утв. ВС РФ 09.10.1992 N 3612-1) (ред. от 01.04.2020) [Электронный ресурс] // Консультант.Плюс. URL: http://www.consultant.ru/document/cons_doc_ LAW_1870/ (дата обращения: 01.03.2021).

${ }^{2}$ Об объектах культурного наследия (памятниках истории и культуры) народов Российской Федерации : федер. закон от 25 июня 2002 г. № 73-ФЗ // Собрание законодательства Российской Федерации. 2002. № 26. Ст. 2519.

${ }^{3}$ Об охране и использовании историко-культурного наследия народов Республики Тыва : закон Респ. Тыва [от 18 янв. 2013 г. № 1772 ВХ-1] // Тувинская правда. 2013. 31 января. С. 5.

${ }^{4}$ Концепция духовно-нравственного развития и воспитания детей и молодежи республики Тыва до 2025 года: постановление Правительства Республики Тыва от 12 февраля 2019 г. N 73 [Электронный ресурс] // Электронный фонд правовых и нормативно-технических документов. URL: http://docs.cntd.ru/document/553106756 (дата обращения: 01.03.2021).
} 
Сеть публичных библиотек Республики Тыва включает в себя 173 библиотеки: 3 республиканских Национальная библиотека РТ, Тувинская республиканская детская библиотека им. К. И. Чуковского, Тувинская республиканская специальная библиотека для незрячих и слабовидящих, а также 170 муниципальных. По состоянию на 1 января 2021 г. общий фонд библиотек республики составил более трех миллионов экземпляров, в том числе около 400 тысяч экземпляров на тувинском языке (16\% от основного фонда). Библиотечный фонд НБ РТ насчитывает более 580 тысяч экземпляров документов, на тувинском языке - 29063 тысяч экземпляров. В структуре библиотеки 17 подразделений, где трудятся 95 сотрудников. Ежегодно библиотека обслуживает более 17 тысяч читателей, книговыдача составляет свыше 400 тыс. экземпляров в год.

Национальная библиотека им. А. С. Пушкина РТ является членом Российской библиотечной ассоциации с 2017 г. В 2018 г. Советом директоров централизованных библиотечных систем республики под руководством И. А. Эртине был принят Устав Тувинской библиотечной ассоциации (БАРТ), которая находится при Национальной библиотеке. В Уставе прописано, что руководитель Ассоциации избирается из состава Совета. В настоящее время руководителем Ассоциации является директор Тувинской республиканской специальной библиотеки для незрячих и слабовидящих А. К. Дагба. Целью Тувинской библиотечной ассоциации является развитие информационных ресурсов библиотек республики и их интеграция в целях повышения качества информационного и библиотечного обслуживания населения на основе внедрения передовых информационно-коммуникационных технологий, в том числе корпоративных.

В 2019 г. приоритетным региональным проектом стал проект Министерства культуры Республики Тыва «Наследие предков (традиции и обычаи) в XXI веке», призванный стать инструментом социальной политики, средством воздействия и воспитания подрастающего поколения. Руководителем проекта является А. К. Аракчаа, заместитель директора по научной и издательской работе НБ РТ.

Для того, чтобы изучить своих читателей, их интересы, в 2019 г. две крупнейшие библиотеки Тувы - НБ РТ и Тувинская республиканская детская библиотека им. К. И. Чуковского - объединились и провели исследование «Популяризация народных традиций и обычаев в XXI веке». Собирались статистические данные, проводилось анкетирование на базе муниципальных библиотек республики. Анкетированием было охвачено 1600 человек, из них 1161 читателей и 70 библиотекарей, средний возраст участников - 27 лет.

Выяснилось, что в фондах библиотек республики насчитывается 1577 экз. книг художественной литературы 11 писателей, т. е. 0,4\% от общего фонда на тувинском языке. В 2019 г. книговыдача детям до 14 лет составила 1512 экз. книг (18\% от общей книговыдачи), молодежи 15-30 лет - 3796 экз. книг $(45,7 \%)$ (Эртине, 2020: 7). Лидерами читательского спроса стали произведения доктора исторических наук, Народного писателя Тувы М. Б. Кенин-Лопсана. В течение 2019 г. его книги были выданы детям 698 раз, молодежи - 1913 раз. Пользовались повышенным спросом, в частности, такие его произведения:

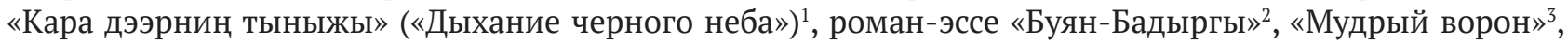
исследования в области этнографии: «Тыва чоннуң бурунгу ужурлары» («Традиционная культура тувинцев») $)^{4}$, «Тыва чаңчыл» («Тувинские обычаи») ${ }^{5}$, «Тувинские шаманы» ${ }^{6}$, «Тыва хамнарнын торулгалары» («Мифы тувинских шаманов) ${ }^{7}$.

Неугасающий интерес у читателей вызывает роман К.-Э. К. Кудажы «Улуг-Хем неугомонный»8 на тувинском языке. Он выдан читателям от 15 до 17 лет 138 раз, молодежи (18-35 лет) - 1425 раз.

\footnotetext{
${ }^{1}$ Кенин-Лопсан М. Б. Кара дээрниң тыныжы = Дыхание черного неба : мифологическое наследие тувинского шаманизма. Кызыл : Тув. кн. изд-во, 2010. 392 с.

${ }^{2}$ Кенин-Лопсан М. Б. Буян-Бадыргы : Ийи томнуг роман-эссе. Кызыл : Новости Тувы, 2000. 544 с. : портр.

${ }^{3}$ Кенин-Лопсан М. Б. Мудрый ворон предсказывает : шаманское наследие тувинского народа : [авторский перевод]. Кызыл : Тываполиграф, 2011. 205 с.

${ }^{4}$ Кенин-Лопсан М. Б. Тыва чоннуң бурунгу ужурлары : ийи кезектиг : улусчу педагогиканың башкыларынга дузаламчы кылдар үндүрген. Кызыл : Тываполиграф, 2013. 528 с.

${ }^{5}$ Кенин-Лопсан М. Б. Тыва чаңчыл : ийи кезектиг / Перераб. изд. Кызыл : Ю. Ш. Кюнзегеш аттыг Тываның ном үндүрер чери, 2017. 359 с.

${ }^{6}$ Кенин-Лопсан М. Б. Тувинские шаманы. М. : Маска, 2009. 325 с. : цв. ил.

${ }^{7}$ Кенин-Лопсан М. Б. Мифы тувинских шаманов = Тыва хамнарнын торулгалары . Кызыл : Новости Тувы, 2002. 543 с.

${ }^{8}$ Кудажы, К.-Э. Улуг-Хем неугомонный : Роман / пер. с тув. А. Китайник. Кызыл : Тувин. кн. изд-во, 1976. Т. 1. 1976. 343 c.; T. 2. 1977.262 c.
} 
Из наиболее читаемых авторов и книг были также: Степан Сарыг-оол «Ангыр-оолдун тоожузу» («Повесть о светлом мальчике») мужские занятия тувинцев» ${ }^{3}$ и Самбуу Иргит «Тыва оюннар = Тувинские игры» ${ }^{4}$ Очевидно, что произведения тувинских писателей, а также издания по традиционной тувинской культуре востребованы среди читателей (Эртине, 2020: 7).

Вопросы анкеты были направлены не только на читательские интересы, но и ставились шире: каких традиций и обычаев придерживаются тувинские семьи в повседневной жизни. Нам назывались: почитание взрослых, угощение чаем, празднование тувинского Нового года Шагаа; семейные обрядовые праздники, очищение помещения окуриванием можжевельника. Большинство опрошенных считают, что в семье должны быть свои традиции, которые перенимались бы будущими поколениями.

На последний открытый вопрос «Ваши рекомендации по совместной работе библиотеки, школы и семьи в приобщении детей к национальным традициям и обычаям» были получены ответы, которые подчеркивали роль и задачи библиотеки в этом направлении (там же).

\section{Роль Национальной библиотеки Тувы в сохранении историко-культурного наследия}

В настоящее время документные собрания библиотек, такие как газеты, редкие и ценные книги, претерпевают значительные изменения, в первую очередь под воздействием цифровизации (Давыдова, 2005: 60). Современные библиотеки учитывают изменившиеся интересы пользователей и способствуют получению ими информации, в том числе на основе новых информационных технологий (Матвеева, 2005: 24; Брескин, 2004: 32). Это соответствует основным направлениям развития библиотек, определенных Международной федерацией библиотечных ассоциаций и учреждений (ИФЛА) как переход библиотек от «хранилища книг» к «провайдерам информационных услуг» (Рябушева, 2004: 27).

НБ РТ является основным книгохранилищем республики и ее главной задачей в первые годы существования было обслуживание жителей столицы республики, проведение культурно-просветительской работы, методическое руководство библиотеками и красными юртами кожуунов (Моллеров, 1989: 119). Пополнение ее фонда краеведческой литературой полноценно начало развиваться с открытием в 1968 г. отдела краеведческой и национальной литературы в Республиканской библиотеке им. А. С. Пушкина. Фонд краеведческой литературы представлял собой часть библиотечного фонда, состоящую из изданий, содержащих сведения о Туве, раскрывающих ее историю, характеризующую выдающихся деятелей. Начальный фонд отдела составил 5120 экз. (Фенцель, 2005: 51). С открытием нового отдела особое внимание библиотеки начали уделять пропаганде краеведческой литературы. На сегодня этот фонд библиотеки составляет 586909 экз., из них: на русском языке - 554957 экз., на тувинском - 29063 экз..$^{5}$

В 2011 г. по результатам проверки Средне-Сибирского управления Росохранкультуры по обеспечению сохранности библиотечных фондов, отнесенных к культурному наследию народов Российской Федерации, был создан утвержденный перечень изданий, названных книжными памятниками. К ним были отнесены 30 папок с рукописными нотами и 319 печатными изданиями XIX и первой половины $\mathrm{XX}$ вв. Они считаются охраняемыми, поскольку обладают «выдающимися духовными, эстетическими, полиграфическими и документирующими свойствами, представляющие общественно значимую научную, историческую и культурную ценность и охраняемые специальным законодательством» ${ }^{6}$

В этой связи для всех библиотек, в том числе НБ РТ, встала задача перевода документов в цифровой формат. В этом же году в рамках Республиканской целевой программы «Модернизация библиотечной системы Республики Тыва» был приобретен планетарный книжный сканер ЭЛАР ПланСкан серии «А»

\footnotetext{
${ }^{1}$ Сарыг-оол, С. Аңгыр-оолдуң тоожузу : ийи номнуг чечен чугаалардан тургустунган. Кызыл : Ю. Ш. Кюнзегеш аттыгТывНҮЧ, 2008. 439 с.

2 Чүлдүм, Ч. М. Тевек : чечен чугаалар, литературлуг сайгарылгалар. Кызыл : ТывНҮЧ, 1996. 176 ap.

${ }^{3}$ Даржа В. К. Традиционные мужские занятия тувинцев. Кызыл : Тувинское книжное изд-во, 2009. Т. 1: Хозяйство. Охота. Рыбалка. 2009. 589 с.

${ }^{4}$ Самбу И. У. Тувинские народные игры. Кызыл : Тув. кн. изд-во, 1978. 140 с.

${ }^{5}$ Отчет о работе библиотеки за 2020 г. / ГБУ «Нац. б-ка им. А. С. Пушкина Респ. Тыва». Кызыл, 2020. С. 3.

${ }^{6}$ ГОСТ 7.87-2003 «Система стандартов по информации, библиотечному и издательскому делу. Книжные памятники»: принят 01.01.2005. М., 2005. С. 7.

${ }^{7}$ Отчет о работе Национальной библиотеки за 2011 год / Нац. б-ка им. А. С. Пушкина Респ. Тыва. Кызыл, 2012. $20 \mathrm{c.}$
} 
В оцифровку были включены книги по признаку исторической, художественной и музейной ценности изданий, с целью создания особых условий для хранения и использования произведений печати. Оцифрованные документы записываются на диски и передаются в сектор книжных памятников.

В 2014 г. был подготовлен выпуск комплексных библиографических и полнотекстовых баз данных, электронных коллекций краеведческой тематики: «Этнокультура старообрядцев Тувы», «История Тувы: к 100-летию установления протектората России над Тувой». Данные работы выполнены с целью изучения, сохранения и использования культурного наследия народов, проживающих в Республике Тыва. Электронные коллекции наряду с библиографической информацией содержат значительные массивы фактических данных и полные тексты: электронную библиотеку (монографии, статьи из научных сборников и периодических изданий). Если за первые два года было оцифровано 412 документов из редкого и краеведческого фондов, то к 01.01.2021 г. количество оцифрованных документов уже составило - 2972.

Открытый доступ для удаленных пользователей к оцифрованным изданиям организован на официальном сайте библиотеки https://tuva-library.ru/. Здесь сформирована и размещена полнотекстовая электронная библиотека «Тува читающая», составляющая 267 краеведческих изданий, из них 133 изданий альманаха «Улуг-Хем» (с 1946 г.) и 24 выпуска «Ученых записок» Тувинского научноисследовательского института языка, литературы и истории (с 1953 г.), 110 отдельных редких и ценных изданий, например «Вестник императорского Русского географического общества» 1958 г.

В 2019 г. Тувинской библиотечной ассоциацией (БАРТ) и НБ РТ был разработан совместный проект «Открывая прошлое», поддержанный Фондом президентских грантов. Проект предусматривает оцифровку периодических изданий Республики Тыва XX века, хранящих на своих страницах официальные документы, сведения об исторических, социально-экономических, культурных событиях. На средства гранта приобретены планетарный сканер для оцифровки документов, а также сервер SUPERMICR 826-9 (при поддержке Министерства культуры Республики Тыва).

В рамках проекта «Открывая прошлое» на сайте Национальной библиотеки, в разделе «Ресурсы» собрана в открытом доступе коллекция периодических изданий, не только из своего фонда, но и других учреждений города Кызыла для сохранения и предоставления пользователям. Надо сказать, что не все периодические издания сохранились в полном комплекте. Газета «Красный пахарь» 1925 г., например, представлена из фонда Российской государственной библиотеки. На 01.03.2021 г. оцифровано 19 номеров таких газет, как: «Revolustug arat» («Революстуг арат» - «Революционный арат» 1937 г. №№ 1-2), «Ленин-Сталинниң тугунуң адаа-биле» («Под знамением Ленина-Сталина» 1942 г., №№ 1-3, 1943 г., №№ 1-2, 5, 6), «Революстуң херели» («Лучи революции», 1941 г., № 4), «Красный пахарь» (1925 г., №№ 14, 20, 28, 29, 31, 32, 33, 37, 38), газета «Шын» («Тувинская правда») 22 комплекта (1936 г., 1951-1971 гг.). Данный список коллекции постоянно пополняется.

В рамках приоритетного ведомственного проекта «Наследие предков (традиции и обычаи) в XXI в.» для сайте библиотеки в разделе «Краеведение» разработана полнотекстовая рубрика «Тыва чоннуң алдын үүжези» («Золотое наследие тувинского народа»): https://tuva-library.ru/contents/117tuvinskie-skazki.html. Здесь можно ознакомиться с устным народным творчеством тувинцев: текстами героического эпоса, волшебных сказкок, песен, загадок, поговорое и пословиц, а также благопожеланий, опубликованных в разных изданиях. На 1.03.2021 г. здесь предоставлено 15 изданий.

Таким образом, современные технологии мультимедиа активно используются в НБ РТ для сохранения и популяризации материального культурного наследия.

\section{Образовательные проекты}

Программно-проектная деятельность библиотек в современных условиях рассматривается как эффективный механизм развития творческой активности библиотечного сообщества, совершенствования форм и методов социального партнерства и привлечения новых источников финансовых ресурсов для развития библиотек.

В первую очередь образовательные проекты направлены на обеспечение доступа к традиционным и электронным источникам знаний и информации. Так, Национальная библиотека им. А. С. Пушкина Республики Тыва стала активным партнёром различных учебных заведений республики, поскольку по-прежнему основной по численности категорией читателей остаются студенты. В отделах социально-экономической и естественно-научной литературы студенты составляют, по данным на 
1 января 2021 г., 66,5\% от общего количества читателей, в общем читальном зале $-72,3 \%$, в отделе национальной и краеведческой литературы $-65,8 \%$, в отделе литературы по искусству $-75,1 \%{ }^{1}$.

Студенты активно участвуют в проводимых с 2009 г. Национальной библиотекой днях молодежной науки, а также научного работника. Мероприятия этих дней включают в себя научно-практические конференции, встречи школьников и студентов с учеными. Количество участников и слушателей этих образовательных мероприятий увеличивается с каждым годом. Так, если в 2014 г. было прочитано всего 18 докладов, слушателей было 48 человек, то в 2020 г. прозвучало уже более 56 докладов и слушателей стало более 200 человек. Участниками «Дней молодежной науки» стали старшеклассники городских школ, студенты, аспиранты, преподаватели образовательных учреждений.

Инициатива «Космический урок», начатая впервые в России научной библиотекой Томского государственного педагогического университета в 2007 г., продолжается теперь в разных городах страны. В 2019 г. «Космический урок» был проведен в онлайн-формате и в Туве. 19 июня в НБ РТ была организована трансляция одного из уроков Международной космической станции (МСК). Во время урока участники из разных городов задавали вопросы членам экипажа - командиру Олегу Кононенко и космонавту Алексею Овчинину (фото 1).

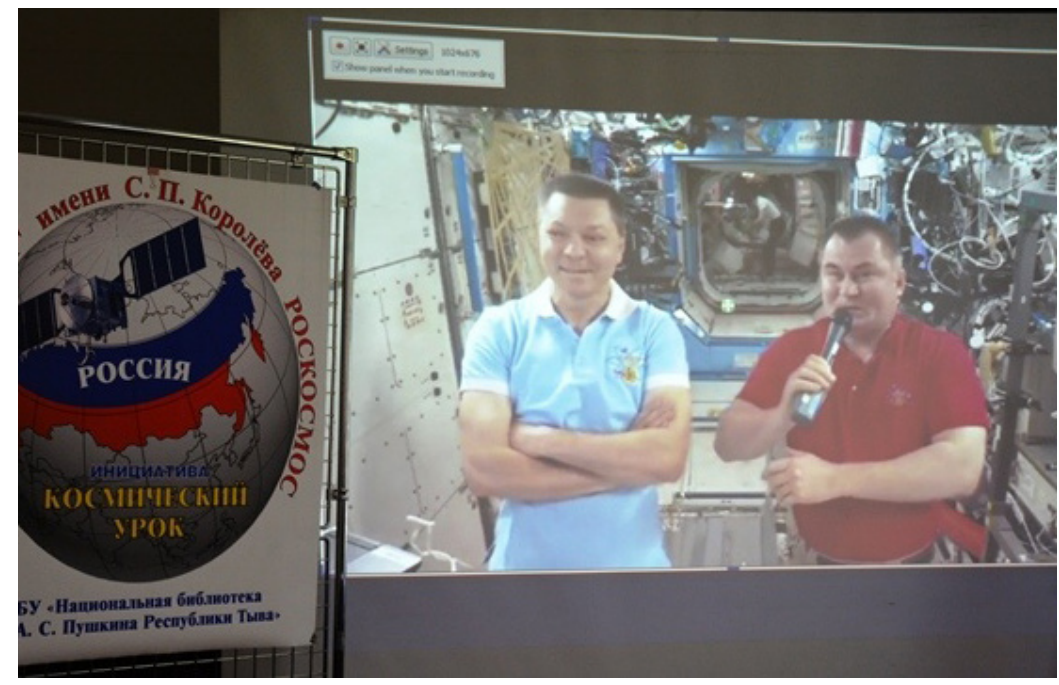

Фото 1. Командир экипажа Олег Кононенко и космонавт Алексей Овчинин во время «Космического урока», 2019 г. Фото А. A. Чan.

Photo 1. Crew commander Oleg Kononenko and cosmonaut Alexey Ovchinin at the "Lesson from space”, 2019. Photo by A. A. Chap.

Проект «Космический урок» - новый формат мероприятий для НБ РТ. Его просветительский характер полностью соответствует одному из направлений деятельности библиотеки - вовлечению школьников в техническое творчество, популяризацию новых научно-технических знаний. Это способствует развитию интереса к таким школьным предметам, как физика, химия, география, математика и др. и в итоге помогает ребятам из Тувы готовиться по ним и успешно сдавать экзамены, поступать в престижные вузы².

При отделах естественно-научной литературы и информационно-библиографической действуют с 2018 г. Малая академия наук и Школа аспиранта. Их работа легла в основу проекта «Библиотека научной молодежи Тувы», который принял участие в благотворительном конкурсе «Новая роль библиотек в образовании» Фонда Михаила Прохорова. В 2019 г. на базе библиотеки открыта секция юных исследователей (руководитель - Ч. Сарыглар). Занятия секции проводятся ежегодно в День российской науки, юные исследователи - это учащиеся младших классов.

${ }^{1}$ Отчет о работе Национальной библиотеки за 2020 год / ГБУ «Нац. б-ка им. А. С. Пушкина Респ. Тыва». Кызыл, 2020. C. 12.

2 «Космический урок» в Национальной библиотеке [Электронный ресурс] // Национальная библиотека Республики Тыва им. Александра Сергеевича Пушкина. URL: https://uva-library.ru/novosti/2116-kosmicheskiyurok-v-natsionalnoy-biblioteke.html (дата обращения: 25.02.2021). 
В 2020 г. стартовал проект «Школа развития личности» (руководитель - Ч. Ондар, заведующая читальным залом, идейный вдохновитель - О. Балчирбай, Почетный работник общего образования РФ). В течение года организаторы провели несколько встреч подростков с творческими людьми разных профессий, реализовавших свои мечты. Это поможет школьникам раскрыть свои таланты и возможности. В рамках социального проекта «Школа развития личности» в Национальной библиотеке РТ планируется проведение занятий для учащихся по подготовке к ЕГЭ и ОГЭ по русскому языку и литературе.

Следующий актуальный проект «БИО-Vita» («Библиотека. Информация. Образование - Жизнь»). Руководитель проекта Л. Санарова, заведующая отделом естественно-научной литературы; научный консультант - д. б. н., проф. У. Н. Кавай-оол. Проект разработан с целью распространения научных знаний среди учащейся и студенческой молодежи. Первое занятие 2 октября 2020 г. было посвящено Николаю Тимофееву-Ресовскому르, русскому ученому, биологу, генетику, которому 20 сентября исполнилось 120 лет со дня рождения. Биография ученого явилась основой документального романа Даниила Гранина «Зубр»². В фонде НБ РТ имеются издания его научного наследия в серии «Памятники отечественной науки» ${ }^{3}$, воспоминания соратников о нем, различные учебные пособия по биологии и справочные издания.

Главная задача образовательной деятельности НБ РТ заключается в обеспечении преемственности от школьных знаний к вузовским, а затем к самообразованию. Отметим, что данные проекты реализуются в режиме диалога. Данные направления работы библиотеки позволяют создавать площадки для перекрестного обсуждения реализующихся национальных проектов, идей и научных исследований.

\section{Социальные проекты}

С 2013 г. в НБ РТ также функционирует проект «Социальная школа “Твори добро” (руководитель Ч. Ондар). Проект направлен на поддержку творческого развития людей старшего возраста. Активисты социальной школы - постоянные участники различных экологических и благотворительных акций («Передай добро по кругу», «Чистые берега» и пр.). Слушатели посещают уроки основ английского разговорного языка и грамматики, занятия по лингвострановедению. Таланты раскрываются и в кружке «Умелые ручки». Совсем недавно в социальной школе открылось новое направление - уроки живописи. Основами рисования и профессиональными приемами с возрастными ученицами охотно делится художник О. Сат. Слушатели социальной школы ведут активный и здоровый образ жизни. По субботам в рамках направления «Активное долголетие» они посещают занятия по каратэ, которые проводит тренер, мастер спорта международного класса, руководитель Федерации каратэ Ч. Алиев. По действующему проекту «Я вырос в том краю, и край мне этот дорог..» продолжаются организованные поездки по выходным дням в различные уголки Тувы. Они позволяют не просто посещать районы республики, но, прежде всего, в занимательной форме заниматься краеведением.

Следующим актуальным направлением просветительской деятельности НБ РТ явилось создание в 2019 г. региональной проектной школы «Проектория», инициатором которого стала к. и. н. В. С. Кан. Под её руководством сотрудники Управления проектной деятельности Администрации Главы и Аппарата Правительства Республики Тыва проводили занятия по общественному обсуждению национальных проектов, реализуемых на территории Тувы. Всего было проведено 10 занятий, в котором приняли участие 407 человек, это: учащиеся образовательных учреждений города, специалисты области культуры, образования и здравоохранения, а также представители проектных отделов министерств республики.

26 сентября 2019 г. стартовал просветительский проект «Выездная библиотека для чабанов» (автор - Ч. Ондар, заведующая читальным залом НБ РТ). Совместно с ведущим методистом научнометодического отдела Ч. Сат организовали выезд к участникам губернаторского проекта «Кыштаг для молодой семьи». Библиомобиль Национальной библиотеки отправилась по просторам Каа-Хемского кожууна на чабанскую стоянку, где живут Сылдыс Владимирович и Айсуу Олеговна Тамылан, в местечке Баян-Кол-Аксы сумона Суг-Бажы Каа-Хемского района.

\footnotetext{
${ }^{1}$ Занятие клуба «Био-Vita». «Зубр» не умел быть великим» (120 лет со дня рождения Н.Тимофеева-Ресовского, российского генетика, биолога) [Электронный ресурc] // youtube.com. URL: https://youtu.be/bQ3503CkQmM

${ }^{2}$ Гранин Д. А. Мой лейтенант. Зубр. М., 2017. 125 с.

${ }^{3}$ Тимофеев-Ресовский Н. В. Избранные труды (1900-1981) / под ред. О. Г. Газенко и В. И. Иванова [сост.:

В. И. Иванов, Н. А. Ляпунова]. М. : Наука, 2009. 510 с.
} 
В 2020 г. по поручению Главы Республики Тыва об увеличении количества выездов для библиотечного обслуживания чабанских стоянок был разработан ведомственный проект с говорящим названием «БиблиоЮрта». На момент написания статьи совершено 65 выезда, охвачено библиотечным обслуживанием 4525 чел. Подобные выезды будут осуществляться для участников регионального проекта «Кыштаг для молодой семьи»'. В 2020 г. также разработаны несколько образовательных и социально-значимых проектов, в том числе «Читает мама, читает папа», направленный на сохранение и укрепление родственных связей с помощью семейного чтения. Руководитель проекта - Р. Оюн. Он реализовывается в сотрудничестве с Управлением федеральной службы исполнения наказаний (УФСИН) по Республике Тыва при поддержке Фонда Президентских грантов. Осужденные-родители в исправительных учреждениях читают литературные произведения разных жанров, это чтение записывается на видео. Оператор проекта О. Ондар делает монтаж видеозаписей, в том числе заменяет фон, редактирует звук, убирает посторонние шумы. При первом же показе подготовленных видеороликов участники были приятно удивлены, увидев себя читающими на фоне юрты, природы и других фонов.

За год работы проекта проделана большая работа с участниками. Были отобраны 25 осужденныхродителей, проведено анкетирование по выявлению читательских интересов, разработаны памятки «Правила чтения», «Выразительное чтение», проведены занятия по технике выразительного чтения, произведена аудиовидеосъёмка. По итогам вручены подарки - USB-флеш накопители детям. Результат проекта - видеозаписи, с помощью которых библиотека старалась помогать восстановить и укрепить семейные связи осужденных и их детей.

Реализация проектов сегодня также является лучшим способом самовыражения, повышения престижа Национальной библиотеки им. А. С. Пушкина РТ, подчеркивания ее роли и значения в местном сообществе.

\section{Культурные проекты}

В 2019 г. в сфере культуры республики приоритетным проектом стал проект «Наследие предков (традиции и обычаи) в XXI в.», направленный на формирование у детей и молодежи духовнонравственных основ личности через обычаи и традиции. Одним из направлений его является популяризация краеведческого наследия республики.

Для этого НБ РТ разработала и сформировала полнотекстовую электронную библиотеку «Тува читающая»: https://tuva-library.ru/elektronnaya-biblioteka. На сегодняшний день пользователи в свободном доступе могут ознакомиться с полными текстами более ста краеведческих изданий. Еще один схожий проект «Открывая прошлое» получил в 2019 г. поддержку Фонда Президентских грантов. Руководитель - Е. Ак-кыс, заведующая отделом национальной и краеведческой литературой НБ РТ. Оцифровываются периодические издания Тувы XX века, на страницах которых публиковались официальные документы, сведения об исторических, культурных событиях, повествования о выдающихся личностях. Смежный проект «Сохраняя память поколений» поддержан Министерством культуры РТ. Ряд отсканированных изданий уже доступен по адресу: https://tuva-library.ru/contents/167otkryivaya-proshloe.html. Здесь выложены архивные издания: газета «Красный пахарь» (1925 г.), из фондов Российской государственной библиотеки (г. Москва), журнал «Под знаменем Ленина-Сталина», газета «Шын» 1936, 1951 гг., журнал «Революстуң херели» 1941 г.

Проект Тувинской библиотечной Ассоциации и Национальной библиотеки Международного онлайн - форума «Через библиотеку - к развитию общества» в 2020 году получил поддержку Российского фонда культуры в рамках Федерального проекта «Творческие люди» - части Национального проекта «Культура». Целью проекта является развитие партнерства, международного и межрегионального сотрудничества библиотек, обмен опытом и эффективными библиотечными практиками. Всего участвовало более 300 человек: из них 100 человек офлайн, $204-$ онлайн, включая представителей зарубежья Национальных библиотек Монголии и Казахстана. Организации - участники были представлены авторитетными библиотечными учреждениями страны: Российской государственной библиотекой, Государственной публичной научно-технической библиотекой Сибирского отделения

${ }^{1}$ В Туве стартует губернаторский проект «Кыштаг для молодой семьи» [Электронный ресурс] // Официальный портал Республики Тыва. 2016, 11 января. URL: https://rtyva.ru/press_center/news/agriculture/22114/ 
Российской академии наук, представителями библиотечной отрасли различной ведомственной подчинённости Уральского федерального округа, Сибирского федерального округа. От Республики Тыва в форуме приняли участие представители трех республиканских библиотек (Национальной библиотеки им. А. С. Пушкина, Тувинской республиканской детской библиотеки им. К. Чуковского и Тувинской республиканской специальной библиотеки для незрячих и слабовидящих), а также ЦБС республики (централизованных библиотечных систем 19 муниципальных образований) и сотрудники научной библиотеки Тувинского государственного университета ${ }^{1}$. Всего в рамках мероприятия прозвучало 30 докладов на следующие темы: библиотека в современном информационно-культурном пространстве; модельные библиотеки нового поколения; сохранение и изучение книжного наследия; библиотека в цифровой среде; краеведческая и издательская деятельность библиотек; библиотека и социальное партнерство; межбиблиотечное взаимодействие: региональный и международный аспект; непрерывное библиотечно-информационное образование. Итогом работы форума стало: удалось наладить дружеские и профессиональные отношения между библиотеками Монголии, Казахстана и России; удалось расширить представление о работе современных библиотек по различным направлениям деятельности, обменяться опытом; готовится к изданию сборник материалов форума.

Можно утверждать, что проектная деятельность необходима и важна для современной библиотеки. Это помогает выстроить взаимодействие с представителями разных сообществ и оценить качество этого взаимодействия, способствует развитию партнерских отношений, помогает привлечь в библиотеку свободные творческие силы и волонтеров.

\section{Заключение}

В статье представлены основные проекты Национальной библиотеки им. А. С. Пушкина Республики Тыва, которая активно участвует в социально-культурной жизни республики. В первую очередь, конечно, она функционирует как центр краеведческой библиографии, культурно-досуговый, информационный центр. Кроме того, она выступает методическим центром для 170 муниципальных библиотек республики. Одной из важных задач, решаемых сегодня библиотекой, является внедрение инновационных методов продвижения книги и чтения, продолжение традиционной работы по формированию у населения устойчивого интереса к чтению. По-прежнему активно ведется работа по пополнению библиотечного фонда исторической и краеведческой литературой, пропаганда книг местных ученых и писателей.

Перевод в цифровой формат историко-культурного наследия Тувы приобретает важную роль в обеспечении прав человека на свободный доступ к редким изданиям. Но все еще существуют проблемы, которые необходимо решать. Прежде всего, это обеспечение оборудованием, а также подготовка специалистов. Приходится учитывать качество конечного изображения, формат, в котором оно хранится, его описание, предназначение и условия сохранности. Требуются соответствующие мероприятия и сложное программное обеспечение.

При этом Национальная библиотека им. А. С. Пушкина Республики Тыва не ограничивается только выполнением своих традиционных задач, внедрением инновационных методов для нее. Библиотека реализует большое количество социальных культурных проектов. За 2018-2020 гг. здесь реализовано 14 проектов с охватом более 6800 человек: учащихся образовательных учреждений республики, молодых ученых и специалистов, даже заключенных; людей самых разных возрастов.

Библиотека как социальный институт выполняет важнейшие социальные функции, не только предоставляя доступ к социально значимым документам для удовлетворения информационных потребностей населения. Сегодня многие национальные библиотеки организуют отдельные коллекции, проекты и создают «обратную связь» от пользователей информации. Социокультурные и технологические изменения в мире определили новую социальную роль библиотек и новые виды работ, благодаря которым библиотеки вносят вклад в развитие культуры региональных сообществ.

${ }^{1}$ Отчет о работе Национальной библиотеки за 2020 год / ГБУ «Нац. б-ка им. А. С. Пушкина Респ. Тыва». Кызыл, 2020. C. 12. 


\section{СПИСОК ЛИТЕРАТУРЫ}

Артемьева, Е. Б. (2012) Эволюция библиотечной сети Сибири и Дальнего Востока в условиях культурно-исторических и социальных трансформаций (XVII-XX вв.). Новосибирск : ГПНТБ СО РАН. 422 с.

Библиотечное обслуживание полиэтнического населения региона (2009) : культурная компетентность библиотекаря : справочное пособие / сост. : Л. Д. Данильянц, В. С. Крейденко. СПб. : Российская нац. б-ка. 166 с.

Брескин, С. Н. (2004) Внедрение информационных технологий в библиотеках Краснодарского края // Через библиотеки - к будущему : сб. материалов по формированию детско-юношеской информ. политики: в 2 ч. / сост. А. Демидов, О. Старовойтова. М. : Школьная библиотека. Ч. 2. 236 с. С. 32-40.

Ванеев, А. Н. (2007) Библиотековедение в России конца XX века : общетеоретические концепции и дискуссии : учебное пособие. СПб. : Профессия. 246 с.

Гузнер, И. А. (1995) Материалы к истории горно-заводских библиотек. Новосибирск : ГПНТБ. 51 с.

Давыдова, Н. Р. (2005) Фонды электронных документов в библиотеке // Научно-технические библиотеки. № 2. С. 60-70.

Дворкина, М. Я (2009) Библиотечная среда: теория и организация. М. : Литера. 112 с.

Карташов, Н. С. (2004) Региональное библиотековедение : науч.-практ. пособие. М. : Либерея. 224 с.

Кожевникова, Л. А. (2007) Методика региональных библиотековедческих исследований: социально-экономический и культурологический подходы : учеб.-метод. пособие. Новосибирск : ГПНТБ СО РАН. 168 с.

Кожевникова, Л. А. (2009) Методологические подходы к исследованию библиотечного пространства // Вестник Дальневосточной государственной научной библиотеки. № 2. С. 23-31.

Кожевникова, Л. А. (2012) Методология регионального библиотековедения: проблемы и перспективы. Новосибирск : ГПНТБ СО РАН. 144 с.

Кошкар-оол, В. А. (1990) Библиотечное строительство в Тувинской АССР : история, современное состояние и перспективы развития : дисс. ... к-та пед. н. Ленинград. 199 с.

Кравченко, Е. В., Фенцель, О. В. (2017) Деятельность Национальной библиотеки им. А. С. Пушкина Республики Тыва по сохранению культурного наследия в традиционном и электронном форматах // Труды ГПНТБ СО РАН. Вып. 12. С. 427-437.

Кукатова, Г. И. (2010) Центральная библиотека региона: современный этап развития : научно-практическое пособие. М. : Литера. 144 с.

Лукьянова, Л. С. (2009) Народные чтения и общества попечения о народной трезвости Тобольской губернии : (вторая половина XIX - XX в.) // Восьмые Макушинские чтения : материалы науч. конф., 13-15 мая 2009 г., г. Красноярск / редкол.: И. В. Лизунова (отв. ред.) и др. Новосибирск: ГПНТБ СО РАН. 407 с. С. 160-164.

Люндуп, Т. М. (2006) История становления и развития методической службы Национальной библиотеки // Круг знания / сост. : О. В. Фенцель, Л. И. Разумова. Кызыл : РИО НБ РТ. Вып. 4. 158 с. С. 12-17.

Маадыр, М. С. (1997) Книжное дело Тувы: Основные этапы и тенденции развития, 1921-1996 гг. : дисс. ... к. ист. н. Новосибирск. 217 с.

Маслова, А. Н. (2010) Краеведение и библиотека : избранные статьи. СПб. : Профессия. 363 с.

Матвеева, И. (2005) Новые черты старой работы // Библиотека. № 3. С. 24-27.

Моллеров, Н. М. (1989) Истоки братства. Русская самоуправляющаяся трудовая колония в Тувинской Народной Республике. Кызыл : Тувинское книжное издательство. 143 с.

Монгуш, 3. М. (2007) Книжная культура Республики Тыва в теоретико-историческом освещении. М. : Пашков дом. 286 с.

Наныкпан, Н. Х. (2016) Основные направления совместной научной деятельности Национальной библиотеки им. А. С. Пушкина Республики Тыва и библиотек муниципальных образований // Труды ГПНТБ СО РАН. Вып. 10. C. 60-68.

Пайчадзе, С. А. (1983) Книга Дальнего Востока: Очерк истории. Хабаровск : Кн. изд-во. 159 с.

Подик, И. В. (2017) Чтение населения Республики Тыва : этнокультурные особенности : автореф.дисс.... к. пед. н. М. 24 c.

Посадсков, А. Л. (2012) Миноритарная национальная пресса в регионах современной России // Девятые Макушинские чтения: материалы научной конференции, 15-16 мая 2012 года / отв. ред. Е. Н. Савенко. Барнаул ; Новосибирск : ГПНТБ СО РАН. 372 с. С. 187-191.

Рябушева Е. Ю. (2004) Юношеская - ориентир на будущее // Молодые в библиотечном деле / отв. ред. Е. Ю. Рябушева. Улан-Удэ : Изд. ГРЮБ РБ. 145 с. С. 27-32.

Сарыглар, Ч. В. (2020) Роль национальной библиотеки Тувы в сохранении историко-культурного наследия // Наследие предков: традиции и обычаи в XXI веке : материалы респ. науч.-практ. конф. (12 февр. 2020 г., г. Кызыл) / сост. М. М. Бадыргы ; науч. ред. М. Б. Кунгаа ; отв. ред. И. А. Эртине. Кызыл : РИО НБ РТ. 82 с. С. 71-73. 
Сарыглар, Ч. В. (2021) Социальные и образовательные проекты в библиотеке: от замысла к реализации // Через библиотеку - к развитию общества : материалы междунар. онлайн-форума (Респ. Тыва, г. Кызыл 15 окт. 2020 г.) / сост. М. М. Бадыргы ; отв. ред. И. А. Эртине. Кызыл : РИО НБ РТ. 99 с. С. 44-48.

Ситников, Л. А. (1985) Книжные сокровища Сибири: Век восемнадцатый. По следам старин. сиб. б-к и их читателей. Новосибирск : Зап.-Сиб. кн. изд-во. 112 с.

Столяров, Ю. Н. (1991) Библиотечный фонд : учеб. для библ. фак. ин-тов культуры, ун-тов и пед. вузов. М. : Кн. палата. 270 с.

Тюлина, Н. И. (1989) Национальная библиотека. Опыт типологического анализа : автореф. дисс. ... д-ра пед. н. M. 33 c.

Фенцель, О. В. (1997а) История и современное состояние комплектования фондов библиотек Тувы. Кызыл : РИО НБ РТ. 24 с.

Фенцель, О. В. (1997b) История формирования фондов библиотек Тувы до 1917 г. Кызыл : РИО НБ РТ. 12 с.

Фенцель, О. В. (2003) Библиотечное краеведение в Республике Тува : прошлое, настоящее, перспективы : автореф. дис. ... канд. пед. наук. СПб. 18 с.

Фенцель, О. В. (2005) От общественной библиотеки - к Национальной библиотеке Республики Тува // Люди и события : год 2006 / сост. : Л. М. Чадамба, Е. М. Ак-кыс. Кызыл : РИО НБ РТ. 98 с. С. 51-54.

Фенцель, О. В. (2011) История становления и развития Национальной библиотеки Республики Тыва (1914-2010 гг.). Кызыл : Нац. б-ка Респ. Тыва. 67 с.

Фенцель, О. В. (2014) Библиотечное дело Тувы в контексте историко-культурного пространства региона. Кызыл : РИО НБ РТ. 24 с.

Фирсов, В. Р. (2000) Государственное законодательное регулирование деятельности библиотек. СПб. : Изд-во Рос. нац. б-ки. 255 с.

Фонотов, Г. П. (2002) Библиотеки - общество - Россия : исслед. социокультур. среды. М. : Либерея. 192 с.

Чадамба, Л. М. (2006) Отдел национальной и краеведческой литературы - центр библиотечного краеведения Тувы // Круг знания / сост. : О. В. Фенцель, Л. И. Разумова. Кызыл : РИО НБ им. А. С. Пушкина РТ. Вып. 4.78 с. C. 17-23.

Эртине, И. А. (2020) Популяризация народных традиций и обычаев в XXI веке в библиотеках Республики Тыва // Наследие предков: традиции и обычаи в XXI веке : материалы респ. науч.-практ. конф. (12 февр. 2020 г., г. Кызыл) / сост. М. М. Бадыргы ; науч. ред. М. Б. Кунгаa ; отв. ред. И. А. Эртине. Кызыл : РИО РТ. 82 с. С. 7-10.

Дата поступления: 08.12.2020 г.

\section{REFERENCES}

Artem'eva, E. B. (2012) Evoliutsiia bibliotechnoi seti Sibiri i Dal'nego Vostoka v usloviiakh kul'turno-istoricheskikh i sotsial'nykh transformatsii (XVII-XX vv.) [The evolution of the library network in Siberia and the Far East in the context of cultural, historical and social transformations in the $17^{\text {th }}-20^{\text {th }}$ centuries]. Novosibirsk, GPNTB SO RAN. 422 p. (In Russ.).

Bibliotechnoe obsluzhivanie polietnicheskogo naseleniia regiona [Library services for the multi-ethnic population of a region] (2009): cultural competence of the librarian: a reference guide / comp. by L. D. Danil'iants and V. S. Kreidenko. St. Petersburg, Russian National Library. 166 p. (In Russ.).

Breskin, S. N. (2004) Vnedrenie informatsionnykh tekhnologii v bibliotekakh Krasnodarskogo kraia [Introduction of information technologies in libraries of the Krasnodar Krai]. In: Cherez biblioteki $-k$ budushchemu [Through libraries to the future]: a collection of materials on the formation of children's and youth information policies: in 2 parts / comp. by A. Demidov and O. Starovoitova. Moscow, Shkol'naia biblioteka. Part 2. 236 p. Pp. 32-40. (In Russ.).

Vaneev, A. N. (2007) Bibliotekovedenie v Rossii kontsa XX veka: obshcheteoreticheskie kontseptsii i diskussii [Library studies in Russia at the end of the twentieth century: general theoretical concepts and debates]: textbook. St. Petersburg, Professiia. 246 p. (In Russ.).

Guzner, I. A. (1995) Materialy k istorii gorno-zavodskikh bibliotek [Materials for the history of libraries at mining factories]. Novosibirsk, GPNTB. 51 p. (In Russ.).

Davydova, N. R. (2005) Fondy elektronnykh dokumentov v biblioteke [Electronic document collections in the library]. Nauchno-tekhnicheskie biblioteki, no. 2, pp. 60-70. (In Russ.).

Dvorkina, M. Ya. (2009) Bibliotechnaia sreda: teoriia i organizatsiia [Library environment: theory and organization]. Moscow, Litera. 112 p. (In Russ.).

Kartashov, N. S. (2004) Regional' noe bibliotekovedenie [Regional library studies]: a guide for researchers and practitioners. Moscow, Libereia. 224 p. (In Russ.).

Kozhevnikova, L. A. (2007) Metodika regional'nykh bibliotekovedcheskikh issledovanii: sotsial'no-ekonomicheskii $i$ kul'turologicheskii podkhody [Methodology of regional library studies: socio-economic and cultural approaches]: a textbook and methodological guide. Novosibirsk, GPNTB SO RAN. 168 p. (In Russ.). 
Kozhevnikova, L. A. (2009) Metodologicheskie podkhody k issledovaniiu bibliotechnogo prostranstva [Methodological approaches to the study of library space]. Vestnik Dal'nevostochnoi gosudarstvennoi nauchnoi biblioteki, no. 2, pp. 23-31. (In Russ.).

Kozhevnikova, L. A. (2012) Metodologiia regional'nogo bibliotekovedeniia: problemy i perspektivy [Methodology of regional library studies: problems and prospects]. Novosibirsk, GPNTB SO RAN. 144 p. (In Russ.).

Koshkar-ool, V. A. (1990) Bibliotechnoe stroitel'stvo v Tuvinskoi ASSR: istoriia, sovremennoe sostoianie i perspektivy razvitiia [Library construction in the Tuvan ASSR: history, current state and prospects of development]: Diss. ... Candidate of Pedagogy. Leningrad. 199 p. (In Russ.).

Kravchenko, E. V. and Fentsel', O. V. (2017) Deiatel'nost' Natsional'noi biblioteki im. A. S. Pushkina Respubliki Tyva po sokhraneniiu kul'turnogo naslediia $\mathrm{v}$ traditsionnom i elektronnom formatakh [The work of the Pushkin National Library of the Republic of Tyva for the preservation of cultural heritage in traditional and electronic formats]. Trudy GPNTB SO RAN, vol. 12, pp. 427-437. (In Russ.).

Kukatova, G. I. (2010) Tsentral'naia biblioteka regiona: sovremennyi etap razvitiia [The central library of the region: the modern stage of development]: a scientific and practical guide. Moscow, Litera. 144 p. (In Russ.).

Luk'ianova, L. S. (2009) Narodnye chteniia i obshchestva popecheniia o narodnoi trezvosti Tobol'skoi gubernii : (vtoraia polovina XIX $-\mathrm{XX}$ v.) [Folk readings and temperance societies of the Tobolsk province: from the second half of the $19^{\text {th }}$ to the end of the 20 th century]. In: Vos'mye Makushinskie chteniia [Eighth Makushin Readings]: proceedings of a research conference, May 13-15, 2009, Krasnoyarsk / ed. by I. V. Lizunova et al. Novosibirsk, GPNTB SO RAN. 407 p. Pp. $160-164$. (In Russ.).

Liundup, T. M. (2006) Istoriia stanovleniia i razvitiia metodicheskoi sluzhby Natsional'noi biblioteki [History of the formation and development of the methodological service of the National Library]. In: Krug znaniia [Circle of Knowledge] / comp. by O. V. Fentsel' and L. I. Razumova. Kyzyl, RIO NB RT. Vol. 4.158 p. Pp. 12-17. (In Russ.).

Maadyr, M. S. (1997) Knizhnoe delo Tuvy: Osnovnye etapy i tendentsii razvitiia, 1921-1996 gg. [Book publishing in Tuva: The main stages and trends of development, 1921-1996]: Diss.... Candidate of History. Novosibirsk. 217 p. (In Russ.).

Maslova, A. N. (2010) Kraevedenie i biblioteka [Local history and the Library]: selected articles. St. Petersburg, Professiia. 363 p. (In Russ.).

Matveeva, I. (2005) Novye cherty staroi raboty [New features of the old work]. Biblioteka, no. 3, pp. 24-27. (In Russ.).

Mollerov, H. M. (1989) Istoki bratstva. Russkaia samoupravliaiushchaiasia trudovaia koloniia v Tuvinskoi Narodnoi Respublike [The origins of the brotherhood. Russian self-governing labor colony in the Tuvan People's Republic]. Kyzyl, Tuvan book publisher. 144 p. (In Russ.).

Mongush, Z. M. (2007) Knizhnaia kul'tura Respubliki Tyva v teoretiko-istoricheskom osveshchenii [Book culture of the Republic of Tyva in theoretical and historical aspects]. Moscow, Pashkov dom. 286 p. (In Russ.).

Nanykpan, N. Kh. (2016) Osnovnye napravleniia sovmestnoi nauchnoi deiatel'nosti Natsional'noi biblioteki im. A. S. Pushkina Respubliki Tyva i bibliotek munitsipal'nykh obrazovanii [Joint research work by the A.S. Pushkin National of the Republic of Tuva and libraries of municipal formations: main aspects]. Trudy GPNTB SO RAN, vol. 10, pp. 60-68. (In Russ.).

Paichadze, S. A. (1983) Kniga Dal'nego Vostoka: Ocherk istorii [The Book of the Far East: An outline of history]. Khabarovsk, Book Publishing House. 159 p. (In Russ.).

Podik, I. V. (2017) Chtenie naseleniia Respubliki Tyva : etnokul'turnye osobennosti [Reading of the population of the Republic of Tuva: ethnocultural features]: Abstract of Diss.... Candidate of Pedagogy. Moscow. 24 p. (In Russ.).

Posadskov, A. L. (2012) Minoritarnaia natsional'naia pressa v regionakh sovremennoi Rossii [Ethnic minority ethnic press in the regions of contemporary Russia]. In: Deviatye Makushinskie chteniia [Ninth Makushin Readings]: proceedings of a research conference, May 15-16, 2012 / ed. by E. N. Savenko. Barnaul, Novosibirsk, GPNTB SO RAN. 372 p. Pp. $187-191$. (In Russ.).

Riabusheva, E. Yu. (2004) Yunosheskaia - orientir na budushchee [Youth is a reference point for the future]. In: Molodye v bibliotechnom dele [Young people in the library business] / ed. by E. Yu. Riabusheva. Ulan-Ude, GRIuB RB Publ. 145 p. Pp. 27-32. (In Russ.).

Saryglar, Ch. V. (2020) Rol' natsional'noi biblioteki Tuvy v sokhranenii istoriko-kul'turnogo naslediia [The role of the National Library of Tuva in the preservation of historical and cultural heritage]. In: Nasledie predkov: traditsii $i$ obychai $v$ XXI veke [Heritage of the ancestors: traditions and customs in the $21^{\text {st }}$ century]: Proceedings of the republican research conference (February 12, 2020, Kyzyl) / comp. by M. M. Badyrgy, ed. by M. B. Kungaa and I. A. Ertine. Kyzyl, RIO NB RT. 82 p. Pp. 71-73. (In Russ.).

Saryglar, Ch. V. (2021) Sotsial'nye i obrazovatel'nye proekty v biblioteke: ot zamysla k realizatsii [Social and educational projects in the library: from concept to implementation]. In: Cherez biblioteku $-k$ razvitiiu obshchestva [From the Library to the development of society]: proceedings of the International journal. online forum (Rep. Tuva, Kyzyl 15 Oct. 2020) / comp. by M. M. Badyrgy, ed. by I. A. Ertine. Kyzyl, RIO NB RT. 99 p. Pp. 44-48. (In Russ.). 
Sitnikov, L. A. (1985) Knizhnye sokrovishcha Sibiri: Vek vosemnadtsatyi. Po sledam starin. sib. b-k i ikh chitatelei [Book treasure of Siberia: The eighteenth century. Tracing the ancient Siberian libraries and their readers]. Novosibirsk, Zap.-Sib. kn. izd-vo. 112 p. (In Russ.).

Stoliarov, Yu. N. (1991) Bibliotechnyi fond [Library Fund]: textbook for library departments of institutes of culture, universities and pedagogical universities. Moscow, Book Chamber. 270 p. (In Russ.).

Tiulina, N. I. (1989) Natsional'naia biblioteka. Opyt tipologicheskogo analiza [National Library: a typological analysis]: Abstract of Diss.... Doctor of Pedagogy. Moscow. 33 p. (In Russ.).

Fentsel', O. V. (1997a) Istoriia i sovremennoe sostoianie komplektovaniia fondov bibliotek Tuvy [History and current state of acquisition of library collections in Tuva]. Kyzyl, RIO NB RT. 24 p. (In Russ.).

Fentsel', O. V. (1997b) Istoriia formirovaniia fondov bibliotek Tuvy do $1917 \mathrm{~g}$. [The history of building the funds of the libraries of Tuva before 1917]. Kyzyl, RIO NB RT. 12 p. (In Russ.).

Fentsel', O. V. (2003) Bibliotechnoe kraevedenie v Respublike Tuva : proshloe, nastoiashchee, perspektivy [Local library studies in the Republic of Tuva: past, present, prospects]: Abstract of Diss.... Candidate of Pedagogy. St. Petersburg. 18 p. (In Russ.).

Fentsel', O. V. (2005) Ot obshchestvennoi biblioteki - k Natsional'noi biblioteke Respubliki Tuva [From the public library to the National Library of the Republic of Tuva]. In: Liudi i sobytiia : god 2006 [People and events : year 2006] / comp. by L. M. Chadamba and E. M. Ak-kys. Kyzyl, RIO NB RT. 98 p. Pp. 51-54. (In Russ.).

Fentsel', O. V. (2011) Istoriia stanovleniia i razvitiia Natsional'noi biblioteki Respubliki Tyva (1914-2010 gg.) [The history of the rise and development of the National Library of the Republic of Tuva (1914-2010)]. Kyzyl, National Library of the Republic of Tyva. 67 p. (In Russ.).

Fentsel', O. V. (2014) Bibliotechnoe delo Tuvy v kontekste istoriko-kul'turnogo prostranstva regiona [Library studies in Tuva in the context of the historical and cultural space of the region]. Kyzyl, RIO NB RT. 24 p. (In Russ.).

Firsov, V. R. (2000) Gosudarstvennoe zakonodatel'noe regulirovanie deiatel'nosti bibliotek [Legislative regulation of library activities]. St. Petersburg, Izd-vo Ros. nats. b-ki. 255 p. (In Russ.).

Fonotov, G. P. (2002) Biblioteki - obshchestvo - Rossiia : issled. sotsiokul'tur. Sredy [Libraries - society - Russia: a study of sociocultural environments]. Moscow, Libereia. 192 p. (In Russ.).

Chadamba, L. M. (2006) Otdel natsional'noi i kraevedcheskoi literatury - tsentr bibliotechnogo kraevedeniia Tuvy [Department of National and Local Literature as a center of local library studies in Tuva]. In: Krug znaniia [The Circle of Knowledge] / comp. by O. V. Fentsel' and L. I. Razumova. Kyzyl, RIO NB im. A. S. Pushkina RT nazvanie izdatel'stva. Vol. 4. 78 p. Pp. 17-23. (In Russ.).

Ertine, I. A. (2020) Populiarizatsiia narodnykh traditsii i obychaev v XXI veke v bibliotekakh Respubliki Tyva [Popularization of folk traditions and customs in the $21^{\text {st }}$ century in the libraries of the Republic of Tuva]. In: Nasledie predkov: traditsii i obychai v XXI veke [Heritage of the ancestors: traditions and customs in the $21^{\text {st }}$ century]: proceedings of a republican research conference (February 12, 2020, Kyzyl) / comp. by M. M. Badyrgy, ed. by M. B. Kungaa and I. A. Ertine. Kyzyl, RIO RT. 82 p. Pp. 7-10. (In Russ.). 